\title{
MATURITY AT HARVEST AFFECTS POSTHARVEST LONGEVITY OF CUT CALATHEA FOLIAGE
}

\author{
L.N.S. Perera ${ }^{1}$, W.A.M. Daundasekera ${ }^{2} *$ and D.S.A. Wijesundara ${ }^{3}$ \\ ${ }^{1}$ Postgraduate Institute of Science, University of Peradeniya, Sri Lanka \\ ${ }^{2}$ Department of Botany, Faculty of Science, University of Peradeniya, Sri Lanka \\ ${ }^{3}$ Royal Botanic Gardens, Peradeniya, Sri Lanka \\ Accepted 09 December 2009
}

\begin{abstract}
Foliage of Calathea aemula, C. lietzei and C. zebrina at four maturity stages, first, second, third and fourth fully expanded leaves (FEL) from the shoot apex, were subjected to vase life assessment in distilled water at $20{ }^{\circ} \mathrm{C}$ and $70 \% \mathrm{RH}$. Leaf rolling was the factor leading to vase life termination. Chlorophyll content significantly decreased during vase life in all three species. The best harvesting maturity in relation to vase life varied among the species. At the time of harvest, chlorophyll content of the $1{ }^{\text {st }} \mathrm{FEL}$ were significantly less than those of the $4^{\text {th }}$ FEL in all three species. However, the chlorophyll content at harvest did not show a significant correlation with subsequent Calathea vase life.
\end{abstract}

Key words: chlorophyll, vase life, leaf rolling

\section{INTRODUCTION}

Genus Calathea (Family: Marantaceae) is native to tropical America and grows best in their native habitat as under-storey plants in humid jungles. Calathea foliage produces colour even under extremely low light and are therefore very popular. Of the cut foliage varieties exported from Sri Lanka, cut foliage of Calathea species has a good demand (pers. comm. with local cut foliage exporters). At present $C$. zebrina, C. insignis, C. ornata and C. musaica are exported from Sri Lanka. Wilting and rolling of leaves leading to short shelf life are the prominent postharvest problems encountered with Calathea. These problems limit the export potential of many attractive Calathea species grown in Sri Lanka.

Harvesting maturity, in the context of commercial maturity is concerned with the timing of harvest to meet particular market requirements (Wills et al., 1998). The correct stage of maturity at harvest is one of the key factors to be considered in order to preserve and prolong the postharvest life of cut foliage (Dole and Wikins, 1999). There is no published information related to harvesting maturity of Calathea spp. and also, there are no specific guidelines available for exporters regarding the correct harvesting maturity. This paper reports the effects of harvesting maturity on the postharvest foliage longevity in three selected species of Calathea.

\section{MATERIALS AND METHODS}

\section{Plant Material}

Healthy first $\left(\mathrm{L}_{1}\right)$, second $\left(\mathrm{L}_{2}\right)$ third $\left(\mathrm{L}_{3}\right)$ and fourth $\left(\mathrm{L}_{4}\right)$ fully expanded leaves (FEL) from the shoot apices of $C$. lietzei E. Morren, C. zebrina (Sims) Lindl. and $C$. aemula Körn. were collected from the Royal Botanic Gardens, Peradeniya, Sri Lanka. The leaves were harvested around 9.00 - 9.30 a.m. using a disinfected secateure. Cut ends of collected leaves were kept immersed in tap water during transportation to the laboratory. The leaves were wiped with cotton swabs moistened with tap water to remove debris and trimmed to a uniform petiole length $(10-15 \mathrm{~cm})$. The trimming was done under tap water to avoid trapping air bubbles (Dole and Wikins, 1999). Individual leaves of each species were placed in glass containers $(11 \mathrm{~cm}$ tall $\times 7 \mathrm{~cm}$ diameter $)$ filled with distilled water to $10-15 \mathrm{~cm}$ height. The vase life experiments were conducted at $20{ }^{\circ} \mathrm{C}$ and $70 \% \mathrm{RH}$ under $24 \mathrm{~h}$ /day cool-white fluorescent lighting.

\section{Experimental Design}

Treatments were arranged in a Completely Randomized Design (CRD) with eight replicate

\footnotetext{
*Corresponding author's email: malkanthid@pdn.ac.lk
} 
leaves for each maturity stage. The experiment was repeated twice.

\section{Assessments}

The leaves were assessed for vase life and chlorophyll content. For vase life assessment, observations were made at two-day intervals after harvest. A self-prepared scale was used to assess the quality of leaves based on freshness (wilting/rolling) and colour as follows: Fresh appearance/No blemish $=4$; Slight loss in freshness/Slight yellowing = 3; Moderate loss of freshness/Moderate yellowing $=2$; Severe loss of freshness/Severe yellowing $=1$. The shelf life was determined as the number of days taken to reach scale 3 .

The chlorophyll content of each leaf was measured non-destructively using a digital chlorophyll meter (SPAD 502 / Spectrum Technologies) soon after harvest and at the end of vase life. The leaf tip was selected as the site for chlorophyll measurement since the first signs of yellowing appear in that region. The change in chlorophyll content during vase life was calculated for each cut leaf by subtracting the chlorophyll content at the end of vase life from that at the time of harvest.

\section{Data Analysis}

The data were analyzed using Statistical Analysis Software (SAS, 1990). The vase life data were analyzed by one-way ANOVA. Data related to chlorophyll content was subjected to two-way ANOVA. Mean separation was accomplished using the least significant difference (LSD). Relationship between the vase life and chlorophyll content at harvest was tested using Pearson's correlation analysis. Data of the duplicate trials gave similar values for the parameters tested. Data related to only one trial is presented here.

\section{RESULTS}

\section{Vase life}

In $C$. aemula, the second and third fully expanded leaves ( $\mathrm{L}_{2}$ and $\left.\mathrm{L}_{3}\right)$ exhibited a significantly higher $(\mathrm{P}<0.05)$ vase life than the first fully expanded leaves $\left(\mathrm{L}_{1}\right)$ (Table 1 ). In $C$. lietzei, the lowest vaselife (5 days) was observed in $\mathrm{L}_{4}$ whereas $\mathrm{L}_{3}$ exhibited the highest vaselife of 14 days. In C. zebrina, a significantly higher $(\mathrm{P}<0.05)$ vase life was exhibited by the first fully expanded leaf $\left(\mathrm{L}_{1}\right)$ compared to more mature leaves. However, the other maturity levels of $C$. zebrina showed a relatively shorter vase life than the other two species tested (Table 1). In all three varieties, the leaves started to roll from their leaf margins before any symptom of yellowing became evident.

\section{Chlorophyll content}

In all three species tested, the $1^{\text {st }}$ FEL $\left(\mathrm{L}_{1}\right)$ contained the least chlorophyll content at the time of harvest (Table 2). Generally, the mean chlorophyll content of the highest mature leaf $\left(\mathrm{L}_{4}\right)$ was significantly $(\mathrm{P}<0.05)$ higher than that of $\mathrm{L}_{1}$. The chlorophyll content of leaves decreased significantly $(\mathrm{P}<0.05)$ during vase life in all three species tested irrespective of the harvesting maturity. The only exception to this pattern was shown by the $\mathrm{L}_{1}$ leaves of $C$. zebrina, where an increase in chlorophyll content was evident by the end of the vase life. Moreover, there was no significant difference in the degree of chlorophyll degradation among leaves of different maturity stages during the vase life except for $\mathrm{L}_{1}$ leaves of $C$. zebrina (Table 2).

A correlation analysis was carried out to test the association between vase life and chlorophyll content at harvest. All three species exhibited a weak correlation (Correlation coefficient $=0.12$, -0.078 and -0.009 for C. lietzei, C. zebrina and $C$. aemula, respectively) for the two factors. None of the Correlation coefficient values were significant $(\mathrm{P}<0.05)$.

Table 1. Mean vase life of Calathea spp. with respect to maturity at harvest.

\begin{tabular}{lcrrc}
\hline Species & \multicolumn{5}{c}{ Vase life (Days)* } \\
\cline { 2 - 5 } & $\mathrm{L}_{1}$ & $\mathrm{~L}_{2}$ & $\mathrm{~L}_{3}$ & $\mathrm{~L}_{4}$ \\
\hline Calathea aemula & $7.25 \mathrm{~b}$ & $11.44 \mathrm{a}$ & $10.50 \mathrm{a}$ & $9.20 \mathrm{ab}$ \\
Calathea lietzei & $9.90 \mathrm{ab}$ & $8.80 \mathrm{~b}$ & $14.00 \mathrm{a}$ & $5.00 \mathrm{~b}$ \\
Calathea zebrina & $15.00 \mathrm{a}$ & $7.30 \mathrm{~b}$ & $5.00 \mathrm{~b}$ & $5.20 \mathrm{~b}$ \\
\hline
\end{tabular}

*Mean values within a row followed by different letters are significantly different at $\mathrm{P} \leq 0.05$ using Duncan's Multiple Range Test $(n=8)$. 
Table 2. Chlorophyll content of cut leaves harvested at different maturity stages at the end and start of vase life.

\begin{tabular}{llllll}
\hline \multirow{2}{*}{ Species } & & \multicolumn{4}{c}{ Chlorophyll content (SPAD Units)* } \\
\cline { 3 - 6 } & & $\mathrm{L}_{1}$ & $\mathrm{~L}_{2}$ & $\mathrm{~L}_{3}$ & $\mathrm{~L}_{4}$ \\
\hline Calathea aemula & Start & $52.31 \mathrm{Aa}$ & $56.48 \mathrm{Ab}$ & $54.87 \mathrm{Aab}$ & $58.56 \mathrm{Ab}$ \\
& End & $37.57 \mathrm{Ba}$ & $45.22 \mathrm{Bb}$ & $43.95 \mathrm{Bab}$ & $46.26 \mathrm{Bb}$ \\
& Difference & $14.70 \mathrm{a}$ & $14.19 \mathrm{a}$ & $10.92 \mathrm{a}$ & $13.30 \mathrm{a}$ \\
\hline Calathea lietzei & Start & $44.32 \mathrm{Ab}$ & $57.05 \mathrm{Aa}$ & $58.21 \mathrm{Aa}$ & $55.27 \mathrm{Aa}$ \\
& End & $40.87 \mathrm{Bb}$ & $50.90 \mathrm{Ba}$ & $40.47 \mathrm{Ba}$ & $44.21 \mathrm{Ba}$ \\
& Difference & $17.80 \mathrm{a}$ & $10.40 \mathrm{a}$ & $9.10 \mathrm{a}$ & $11.03 \mathrm{a}$ \\
\hline Calathea zebrina & Start & $34.26 \mathrm{Aac}$ & $35.03 \mathrm{Ac}$ & $36.70 \mathrm{Ac}$ & $39.80 \mathrm{Ad}$ \\
& End & $37.00 \mathrm{Ba}$ & $25.83 \mathrm{Bb}$ & $28.30 \mathrm{Bb}$ & $26.73 \mathrm{Bb}$ \\
& Difference & $-2.70 \mathrm{a}$ & $12.80 \mathrm{~b}$ & $12.46 \mathrm{~b}$ & $13.06 \mathrm{~b}$ \\
\hline
\end{tabular}

*Mean values within a column for each species, followed by different letters are significantly different at $\mathrm{P} \leq 0.05$ using Least Significant Difference (LSD). Uppercase letters denote significance between Start to End values and the lowercase letters denote significance among maturity stages $(n=8)$.

\section{DISCUSSION}

The best maturity stage for harvesting varied among the Calathea species tested. This observation agrees with many other ornamental crops that have been studied (Dole and Wikins, 1999). The findings further indicate that vase life experiments are useful in identifying the best maturity stage for harvesting of foliage in a given species.

The postharvest quality of Calathea cut foliage depended both on wilting (loss of freshness) and yellowing. These may be attributed mainly to the loss of turgidity accompanied by chlorophyll degradation (Petridou et al., 2001). The photosynthetic capacity depends on the developmental stage of leaves (Campostrini et al., 2001) and therefore, the carbohydrate levels of foliage at harvest also may have contributed to the differences in vase life exhibited by them.

Generally, younger developing leaves undergo rapid senescence due to high metabolic rates (Smith et al., 1995). A similar behaviour may have resulted in a relatively shorter vase life of the first fully expanded leaves of Calathea. However, in C. zebrina, the first fully expanded leaves exhibited longer vase life. As indicated by the increase of chlorophyll content during vase life, it may be that the younger leaves in $C$. zebrina continued photosynthesis more efficiently than the rest of the leaves during vase life experiment (Reid et al., 2002). However, to confirm this, a dry weight analysis of leaves would be necessary.
In all three species tested, older leaves contained higher amounts of chlorophyll than chronologically younger leaves, at the time of harvest. This agrees with the pattern reported for foliage including ornamental species like Gazania splendens (Cevahir et al., 2004). However, the Correlation analysis does not warrant the suitability of the chlorophyll content of leaves as an index for selection of the best harvesting maturity. The reduction of chlorophyll content during vase life may be attributed to accelerated senescence of the harvested leaves where the loss of protein or chlorophyll content is a general indication for ageing process (Smith et al., 1995).

In conclusion, even a slight difference in the maturity of leaves at harvest contributes largely to the postharvest longevity of Calathea species tested. The best harvesting maturity was species dependent. Among the maturity stages tested, only the $1^{\text {st }}$ FEL of $C$. zebrina and the $3^{\text {rd }}$ FEL of C. leitzei exhibited the minimum vase life (14 days) acceptable for exportation (pers. comm. with local cut foliage exporters). Further testing of the results of this preliminary study under simulated air-transportation conditions followed by vase life experiments would be useful for determination of the suitability of the above Calathea species for exportation. 


\section{ACKNOWLEDGEMENTS}

The authors wish to acknowledge the Sri Lanka Council for Agricultural Research Policy (CARP) for funding the study.

\section{REFERENCES}

Campostrini, E., Yamanishi, O.K. and Martinez, C.A. (2001). Leaf gas exchange characteristics of four papaya genotypes during different stages of development. Revista Brasileira de Fruticultura 23 (3): 522-525.

Cevahir, G., Yentur, S., Yazgan, M., Unal, M. and Yilmazer, N. (2004). Peroxidase activity in relation to anthocyanin and chlorophyll content in juvenile and adult leaves of "Mini-star", Gazania splendens. Pakistan Journal of Botany 36 (3): 603-609.

Dole, J. M. and Wikins, H.F. (1999). Floriculture principles and species. Prentice Hall, New Jersey Pp.123-137.
Petridou, M., Voyiatzi, C. and Voyiatzi, D. (2001). Methanol, ethanol and other compounds retard leaf senescence and improve the vase life and quality of cut chrysanthemum flowers. Postharvest Biology and Technology 23: 79-83.

Reid, M.S., Wollenweber, B. and Serek, M. (2002). Carbon balance and ethylene in the postharvest life of flowering Hibiscus. Postharvest Biology and Technology 25: 227233.

Smith, B.N., Lytle, C.M. and Hansen, L.D. (1995). Predicting plant growth rates from dark respiration rates: an experimental approach. Proceedings of the Wildland Shrub and Arid Land Restoration Symposium, Las Vegas, NV, Pp.243-245.

Wills, R., McGlasson, B., Graham, D. and Joyce, D. (1998). Postharvest: An introduction to the physiology and handling of fruit, vegetables and ornamentals. UNSW Press, Australia 1-262. 